University of Nebraska - Lincoln

DigitalCommons@University of Nebraska - Lincoln

$12-18-2015$

\title{
Assessment of Selected Antibiotic Resistances in Ungrazed Native Nebraska Prairie Soils
}

Lisa M. Durso

USDA-ARS, Lisa.Durso@ars.usda.gov

David A. Wedin

University of Nebraska-Lincoln, dwedin1@unl.edu

John E. Gilley

USDA-ARS, john.gilley@ars.usda.gov

Daniel N. Miller

USDA-ARS, dan.miller@ars.usda.gov

David B. Marx

University of Nebraska-Lincoln, david.marx@unl.edu

Follow this and additional works at: https://digitalcommons.unl.edu/usdaarsfacpub

Durso, Lisa M.; Wedin, David A.; Gilley, John E.; Miller, Daniel N.; and Marx, David B., "Assessment of Selected Antibiotic Resistances in Ungrazed Native Nebraska Prairie Soils" (2015). Publications from USDA-ARS / UNL Faculty. 1568.

https://digitalcommons.unl.edu/usdaarsfacpub/1568

This Article is brought to you for free and open access by the U.S. Department of Agriculture: Agricultural Research Service, Lincoln, Nebraska at DigitalCommons@University of Nebraska - Lincoln. It has been accepted for inclusion in Publications from USDA-ARS / UNL Faculty by an authorized administrator of DigitalCommons@University of Nebraska - Lincoln. 


\title{
Assessment of Selected Antibiotic Resistances in Ungrazed Native Nebraska Prairie Soils
}

\author{
Lisa M. Durso, * David A. Wedin, John E. Gilley, Daniel N. Miller, and David B. Marx
}

\begin{abstract}
The inherent spatial heterogeneity and complexity of antibioticresistant bacteria and antibiotic resistance (AR) genes in manureaffected soils makes it difficult to sort out resistance that can be attributed to human antibiotic use from resistance that occurs naturally in the soil. This study characterizes native Nebraska prairie soils that have not been affected by human or food-animal waste products to provide data on background levels of resistance in southeastern Nebraskan soils. Soil samples were collected from 20 sites enumerated on tetracycline and cefotaxime media; screened for tetracycline-, sulfonamide-, $\beta$-lactamase-, and macrolide-resistance genes; and characterized for soil physical and chemical parameters. All prairies contained tetracyclineand cefotaxime-resistant bacteria, and $48 \%$ of isolates collected were resistant to two or more antibiotics. Most (98\%) of the soil samples and all 20 prairies had at least one tetracycline gene. Most frequently detected were $\operatorname{tet}(\mathrm{D}), \operatorname{tet}(\mathrm{A}) \operatorname{tet}(\mathrm{O}), \operatorname{tet}(\mathrm{L})$, and tet(B). Sulfonamide genes, which are considered a marker of human or animal activity, were detected in $91 \%$ of the samples, despite the lack of human inputs at these sites. No correlations were found between either phenotypic or genotypic resistance and soil physical or chemical parameters. Heterogeneity was observed in AR within and between prairies. Therefore, multiple samples are necessary to overcome heterogeneity and to accurately assess AR. Conclusions regarding AR depend on the gene target measured. To determine the impacts of food-animal antibiotic use on resistance, it is essential that background and/or baseline levels be considered, and where appropriate subtracted out, when evaluating AR in agroecosystems.
\end{abstract}

\section{Core Ideas}

- Native Nebraska prairie soils have measurable amounts of antibiotic resistance.

- Phenotypic and genotypic measures of resistance vary within and between sites.

- Ungrazed prairie soils can provide background data on resistance in Nebraskan soils.

- Assessments of resistance on farms should include the collection of background data.

- Background resistance should be considered when measuring impact of management.

Copyright $\odot$ American Society of Agronomy, Crop Science Society of America, and Soil Science Society of America. 5585 Guilford Rd., Madison, WI 53711 USA.

All rights reserved.

J. Environ. Qual.

doi:10.2134/jeq2015.06.0280

Supplemental material is available online for this article.

Received 5 June 2015.

Accepted 8 Sept. 2015.

*Corresponding author (lisa.durso@ars.usda.gov).
A NTIBIOTIC-RESISTANT bacteria and antibiotic resistance (AR) genes occur naturally in soil and water from around the globe (Allen et al., 2010; D'Costa et al., 2006; D’Costa et al., 2007; Durso et al., 2012; Cytryn, 2013). Recent studies have highlighted the potential for soil-borne antibiotic-resistant bacteria and AR genes to affect human clinical outcomes, and it has been proposed that many important AR genes originally came from bacteria living in soil (Fosberg et al., 2012; Wright, 2010). In addition to soils' hypothesized natural capacity to contribute to antibiotic-resistant disease in humans, soil is thought to serve as a sink and transport medium for resistance associated with human use of antibiotic drugs via land application of waste products from municipal wastewater, hospitals, pharmaceutical and industrial manufacturing, and agriculture (Ashbolt et al., 2013; Rutgersson et al., 2014; Koh et al., 2015; Amos et al., 2015; Williams-Nguyen et al., 2015).

Studies that characterize antibiotic-resistant bacteria and AR genes in animal manure-affected soils provide valuable information on what is currently present in a sample site. However, if background and baseline levels of AR are not collected, measurements taken in these manure-affected soils can result in conflated data. It is difficult to sort out the resistance that is a result of human antibiotic use from the resistance that is a result of the inherent spatial heterogeneity, complexity, and dynamics of antibiotic-resistant bacteria and AR genes in soils.

One way to start to address this problem is to characterize soils that have been minimally affected by human or food-animal waste products. These areas can be difficult to identify, especially when one requires documentation that specific land has not been grazed by cattle, sheep, goats, or other food animals in the past. In Nebraska, where the majority of land has been converted to agricultural uses, the main candidates for these kinds of background data collections are land that is used for cemeteries and land that is conserved as prairies (Fierer et al., 2013). In this study, soils were collected from native prairies where the landowners could confirm no grazing by food animals (including no accidental grazing) for at least the last $20 \mathrm{yr}$.

L.M. Durso, J.E. Gilley, and D.N. Miller, USDA-ARS, AMRU, 121 Keim Hall, Univ. of Nebraska-Lincoln-East Campus, Lincoln, NE 68583; D.A. Wedin, School of Natural Resources, 411 Hardin Hall, Univ. of Nebraska, Lincoln, NE 68583; D.B. Marx, Dep. of Statistics, 340 Hardin Hall, Univ. of Nebraska, Lincoln, NE 68583. Mention of trade names or commercial products in this article is solely for the purpose of providing specific information and does not imply recommendation or endorsement by the USDA. Assigned to Associate Editor Kari Dunfield.

Abbreviations: agBMPs, agricultural best management practices; $A R$, antibiotic resistance; CLSI, Clinical Laboratory Standards Institute; PCR, polymerase chain reaction. 
With over 49,000 farms and ranches covering $92 \%$ of the state's total land area, Nebraska is one of the nation's top agricultural states. Over 5 million cattle are fed and marketed each year on 4570 cattle feeding operations statewide (USDA National Statistics Service, 2012). Because of the large footprint of animal agriculture in the state, Nebraska is an appropriate place to investigate agriculturally affected AR in soils. Although the majority of the Nebraska land area is involved in agriculture, there is also a network of native prairie sites being preserved by groups such as The Wachiska Audubon Society and the Nebraska Games and Parks Commission in conjunction with private landowners. The native prairie sites have similar soil types to the surrounding agricultural land and have been exposed to similar macroecologic conditions (i.e., temperature, precipitation). As such, they can provide useful information on naturally occurring resistance in southeastern Nebraska, including estimates of resistance in the absence of agricultural inputs and estimates of how the measured parameters are distributed within and between locations.

There is broad agreement in both scientific and policy communities that AR in agroecosystems needs to be reduced. However, in the absence of data on the levels and types of resistance that occur in minimally affected settings, it is difficult to set realistic targets for reduction. Additionally, even when a specific drug type, bacteria, or gene is identified as a means to measure resistance, little data are available to determine the variability for the chosen parameter within a sample, site, or region.

The goal of this study was to characterize selected phenotypic and genotypic AR traits in native southeastern Nebraskan prairie soils. To minimize potential sources of variation, sites were selected based on geographic proximity, and all sample collections were performed within the same week. Our working hypothesis was that the background levels of resistance for each of the measured parameters would be similar within and between the tested prairies.

\section{Materials and Methods}

\section{Prairie Sites}

Potential prairie sites were identified in collaboration with the University of Nebraska School of Natural Resources, The Wachiska Audubon Society, and the Nebraska Games and Parks Commission. Land owners were contacted individually to obtain information on land status and history, to verbally confirm that the land had not been purposefully or accidentally grazed in the last $20 \mathrm{yr}$, and to obtain permission to collect samples. Twenty sites in five counties were chosen for the study (Table 1; Supplemental Fig. S1). The counties that were sampled are located in the part of Nebraska that was originally categorized as upland tall grass prairie.

\section{Soil Sampling}

Soil sampling was conducted in July 2012. Within each prairie, five spatially separated sites were chosen for sampling. Each sample consisted of six 30-cm-deep cores obtained using a step-on soil probe (19.2 $\mathrm{mm}$ i.d.). Due to exceptionally dry or rocky conditions, samples from Prairies 3, 7, and 19 consisted of a total of 12 cores $15 \mathrm{~cm}$ deep, and Prairies 1 and 2 were a mix of full and half cores. For each site, all cores were placed in a whirl-pac bag and returned to the laboratory in a cooler with ice within $4 \mathrm{~h}$ of collection. At the laboratory, whirl-pack bags were removed from the cooler and homogenized by hand before removing aliquots for bacterial plating (resulting in bacterial isolates), soil physical and chemical analysis, and DNA isolation of bulk soil extracts (described below).

Table 1. Prairie sites.

\begin{tabular}{|c|c|c|c|c|}
\hline Prairie ID & County & Area & Name & GPS coordinates \\
\hline & & ha & & \\
\hline 1 & Lancaster & 23.9 & 9 Mile Prairie East (UNL) & $40^{\circ} 52^{\prime} 0.88^{\prime \prime} \mathrm{N} 96^{\circ} 48^{\prime} 29.5^{\prime \prime} \mathrm{W}$ \\
\hline 2 & Lancaster & 64.6 & 9 Mile Prairie West (UNL) & $40^{\circ} 52^{\prime} 4.71^{\prime \prime} \mathrm{N} 96^{\circ} 49^{\prime} 8.8^{\prime \prime} \mathrm{W}$ \\
\hline 3 & Pawnee & 4.1 & Private $\mathrm{A}$ & private land $\dagger$ \\
\hline 4 & Pawnee & 5.4 & Private B & private land \\
\hline 5 & Pawnee & 5.5 & Private C & private land \\
\hline 6 & Pawnee & 4.5 & Private $\mathrm{D}$ & private land \\
\hline 7 & Richardson & 3.8 & Camp Cornhusker & $40^{\circ} 00^{\prime} 0.9^{\prime \prime} \mathrm{N} 95^{\circ} 56^{\prime} 0.1^{\prime \prime} \mathrm{W}$ \\
\hline 8 & Pawnee & 15.4 & Private $\mathrm{E}$ & private land \\
\hline 9 & Otoe & 5.2 & Dieken (Wachiska Audubon) & $40^{\circ} 40^{\prime} 03.8^{\prime \prime} \mathrm{N} 96^{\circ} 17^{\prime} 26.7^{\prime \prime} \mathrm{W}$ \\
\hline 10 & Pawnee & 6.4 & Private $\mathrm{F}$ & private land \\
\hline 11 & Pawnee & 12.9 & Private G & private land \\
\hline 12 & Pawnee & 4.1 & Private $\mathrm{H}$ & private land \\
\hline 13 & Pawnee & 7.9 & Private I & private land \\
\hline 14 & Pawnee & 6.4 & Klapka (Wachiska Audubon) & $40^{\circ} 08^{\prime} 33.59^{\prime \prime} \mathrm{N} 96^{\circ} 04^{\prime} 02.48^{\prime \prime} \mathrm{W}$ \\
\hline 15 & Lancaster & 30.5 & Lincoln Airport Authority Meadow & $40^{\circ} 52^{\prime} 19.72^{\prime \prime} \mathrm{N} 96^{\circ} 48^{\prime} 21.53^{\prime \prime} \mathrm{W}$ \\
\hline 16 & Lancaster & 9.6 & Mitchell Prairie (UNL) & $40^{\circ} 37^{\prime} 34.34^{\prime \prime} \mathrm{N} 96^{\circ} 42^{\prime} 13.67^{\prime \prime} \mathrm{W}$ \\
\hline 17 & Johnson & 3.9 & Private J & private land \\
\hline 18 & Lancaster & 6.7 & Prairie Pines (UNL) & $40^{\circ} 50^{\prime} 34.61^{\prime \prime} \mathrm{N} 96^{\circ} 33^{\prime} 35.25^{\prime \prime} \mathrm{W}$ \\
\hline 19 & Johnson & 4.2 & Table Rock State Wildlife Management Area & $40^{\circ} 24^{\prime} 02.45^{\prime \prime} \mathrm{N} 96^{\circ} 13^{\prime} 01.69^{\prime \prime} \mathrm{W}$ \\
\hline 20 & Pawnee & 13.7 & Wildcat (Wachiska Audubon) & $40^{\circ} 15^{\prime} 10.38^{\prime \prime} \mathrm{N} 96^{\circ} 10^{\prime} 43.85^{\prime \prime} \mathrm{W}$ \\
\hline
\end{tabular}

† Location data for private land are available on request after consultation with private landowners. 


\section{Soil Physical and Chemical Analysis}

Moisture content was determined for $5 \mathrm{~g}$ of soil by mass loss on drying at $105^{\circ} \mathrm{C}$ for $24 \mathrm{~h}$. Additional physical and chemical parameters, including organic matter, potassium, sulfate, zinc, iron, manganese, copper, calcium, magnesium, sodium, nitrate, ammonium, Mehlich P, and excess lime, were measured by Ward Laboratories. Soil samples for these analyses were shipped on ice and analyzed within $48 \mathrm{~h}$ of collection.

\section{Bacterial Culture and Characterization}

After homogenization of the soil samples, $10 \mathrm{~g}$ of soil was weighed out into a fresh whirl-pack filter bag, $90 \mathrm{~mL}$ of sterile phosphate-buffered saline (ThermoFisher Scientific) was added, and bags were manually mixed. Escherichia coli, total coliforms, and Enterococcus were enumerated using Quantitray (IDEXX Laboratories). Escherichia coli and total coliform trays were incubated at $37^{\circ} \mathrm{C}$ for 24 to $28 \mathrm{~h}$, and Enterococcus trays were incubated at $42^{\circ} \mathrm{C}$ for $24 \mathrm{~h}$.

Phenotypic enumeration of selected ARs was performed on the 100 bulk soil samples, and isolates were picked from these plates for further characterization. For soil bacterial colony counts, soil samples $(n=100$; five sites from each of 20 prairies) were plated onto R2A (Becton Dickinson), R2A with tetracycline (TR2A) $\left(16 \mu \mathrm{g} \mathrm{mL}^{-1}\right)$, and R2A with cefotaxime (CR2A) $\left(4 \mu \mathrm{g} \mathrm{mL}^{-1}\right)$ using an Eddy Jet spiral plater (Neutec Group). Tetracycline was chosen because it is commonly assayed in environmental samples. Cefotaxime was chosen as a representative of third-generation cephalosporins, which are used to treat hospital-acquired infections and invasive Salmonella infections in children (Fey et al., 2000). Where necessary to obtain statistically appropriate colony counts on the plates, samples were serially diluted before being spiral plated. Plates were incubated at $37^{\circ} \mathrm{C}$ for 18 to $24 \mathrm{~h}$ and enumerated using a standard spiral plate procedure (Gilchrist et al., 1973). Three isolates were picked for each sample from the plain R2A plates ( $n=300$ isolates), struck for isolation, grown overnight, and frozen at $-80^{\circ} \mathrm{C}$ for later characterization. Disk diffusion assays were performed on isolates according to standard Clinical Laboratory Standards Institute (CLSI) methods using Mueller-Hinton broth (Becton-Dickinson) on 150-mm $\times 15$-mm plates (CLSI, 2012). The CLSI clinical breakpoints were used to assign isolates sensitive or resistant status, and isolates displaying intermediate levels of resistance were counted as sensitive. Twelve drugs were used in the disk diffusion assays: amoxicillin/clavulanic acid $20 \mu \mathrm{g}$, ampicillin $10 \mu \mathrm{g}$, cefoxitin $30 \mu \mathrm{g}$, ceftriaxone $30 \mu \mathrm{g}$, chloramphenicol $30 \mu \mathrm{g}$, ciprofloxacin $5 \mu \mathrm{g}$, gentamycin $10 \mu \mathrm{g}$, kanamycin $30 \mu \mathrm{g}$, nalidixic acid $30 \mu \mathrm{g}$, streptomycin $10 \mu \mathrm{g}$, sulfamethoxazone trimethoprim $25 \mu \mathrm{g}$, and tetracycline $30 \mu \mathrm{g}$.

\section{Polymerase Chain Reaction}

Polymerase chain reaction (PCR) detection of selected AR genes was performed on the 100 bulk soil samples. DNA isolations were performed on each of the bulk soil samples $(n=$ 100) using the MoBio PowerSoil kit according to the manufacturer's directions, except that a Mini Beadbeater-8 (Biospec Products) was used for the cell lysis step. Qualitative tetracycline resistance gene assays were performed as previously described (Ng et al., 2001) with the exception that Jumpstart RedTaq Master Mix (Sigma) was used. Four multiplex reactions were run, evaluating 14 tetracycline resistance genes. Positive control strains were created by cloning the target PCR fragment into TOP10 E. coli cells using a TOPO TA Cloning Kit for Subcloning, with One Shot TOP10 chemically competent E. coli cells (Life Technologies), and are available on request. Two sulfonamide resistance genes, $\operatorname{sul}(\mathrm{I})$ and $\operatorname{sul}(\mathrm{II})$, were assayed using primers described by Pei et al. (2006). Two ermB PCRs were performed as previously described (Böckelmann et al., 2009; Chen et al., 2007). Polymerase chain reactions for $\beta$-lactamases were performed. CTX-M was chosen to represent extended-spectrum $\beta$-lactamases (Cottell et al., 2013), and CMY-2 was chosen to represent class C $\beta$-lactamases (Kozak et al., 2009). Samples that were positive in the qualitative PCR for tet(A) and $\operatorname{sul}(\mathrm{I})$ genes were quantified using QuantiTect SYBR Master Mix (Qiagen) or 5Prime RealMasterMix SYBR ROX (5Prime) with the same primers used for quantitative PCR. All quantitative PCR assays were performed in triplicate. Reported values were determined by comparison with a standard curve for each of the assayed genes and normalized based on grams dry weight of the original soil sample. Primer sequences, PCR recipes, and thermocycling conditions are listed in Supplemental Tables S1 and S2.

\section{Data Analysis}

Microbial abundance data (coliforms, enterococci, R2A counts, R2A + tetracycline, and R2A + cefotaxime) were log transformed before statistical analysis. The GLM procedure of SAS (SAS Institute, 2008) was used to determine differences between prairies for the various microbial abundances. For each microbial abundance, differences between specific prairies were determined using Tukey's Studentized range test. Significant correlations $(P<0.05)$ between microbial abundances and various soil and physical parameters were identified using Pearson correlation coefficients. Principal components analysis using the PRINCOMP procedure of SAS was used to determine if the prairies clustered into discrete groups based on the presence of 17 AR genes in soil DNA extracts.

\section{Results}

\section{Resistance in Native Nebraska Prairie Soils}

Phenotypically, all 100 native Nebraska prairie soil samples collected in this study contained bacteria that were resistant to tetracycline and cefotaxime (defined as bacterial colonies growing on an agar plate containing $16 \mu \mathrm{g} \mathrm{mL}^{-1}$ tetracycline or $4 \mu \mathrm{g} \mathrm{mL}^{-1}$ cefotaxime). Genotypically, carriage of tetracycline genes in bulk soil DNA extracts was common. Specifically, $98 \%$ of soil samples had at least 1 of the 14 tetracycline genes assayed, and tetracycline resistance genes were found in all 20 prairies. Carriage of sulfonamide resistance genes was common, with $91 \%$ of the soil samples positive for either $\operatorname{sul}(\mathrm{I})(91 \%)$ or $\operatorname{sul}(\mathrm{I})$ and $\operatorname{sul}(\mathrm{II})(21 \%)$. None of the bulk soils was positive for sul(II) only. On the prairie level, the $\operatorname{sul}(\mathrm{I})$ gene was found in all 20 prairies, and the sul(II) gene was found in 13. Principal components analysis indicated that the incidence of the 17 specific genes in soil samples yielded no discrete clusters within 
prairies (Supplemental Fig. S2). Prairie \#15 (LAA) was identified as a possible outlier influenced by a positive tet $(\mathrm{X})$ detection and high incidence of tet $(\mathrm{B})$ and tet $(\mathrm{S})$. The $\mathrm{erm}(\mathrm{B})$ gene was not detected in any of the soil samples, with either of the two erm (B) PCR protocols used (only PCR controls were positive). The CTX-M and CMY-2 genes were also not observed in any of the samples. No correlations were found between phenotypic or genotypic AR and soil physical or chemical parameters. Results for soil physical and chemical measurements are presented in Supplemental Table S3. Of note, the term "native" refers to the composition and genetics of the plant species in the prairie and does not indicate whether or not the land was historically cultivated. Although many of the prairie remnants we studied are unplowed (i.e., "virgin" prairie), some may have been cultivated since settlement in the mid-1800s.

\section{Tetracycline Resistance Genes}

The average number of tetracycline gene types per bulk soil sample ( $n=100$ soil samples total) was 3 (SD, 1.4 ), with a range of 0 to 7 positive, out of 14 total tetracycline genes examined. The most frequently detected tetracycline genes in Nebraska prairie soil samples were tet $(\mathrm{D})$ ( $n=54$ of 100 bulk soil extracts) and tet(A) $(n=52)$, with 25 soils positive for both genes (Fig. 1). Other tetracycline resistance genes that were positive in $>25 \%$ of the soils were tet $(\mathrm{O})(38 \%)$, tet $(\mathrm{L})(36 \%)$, and tet $(\mathrm{B})(26 \%)$. Of the 100 soil samples tested, two were negative for all tetracycline genes tested, and 11 were positive for only 1 of the 14 genes assayed. One soil sample was positive for seven tetracycline resistance genes, and four were positive for six tetracycline resistance genes. Examining the data on the level of prairie (combining results from all five soil samples at each prairie), 18 and 19 prairies were positive for tet $(\mathrm{A})$ and tet $(\mathrm{D})$, respectively, and 17 of the 20 prairies were positive for both $\operatorname{tet}(\mathrm{A})$ and $\operatorname{tet}(\mathrm{D})$ genes. The least frequently detected tetracycline genes were $\operatorname{tet}(\mathrm{Q})(n$ $=0)$ and $t e t(\mathrm{X})$ (two soil samples from two different prairies).
Statistically significant differences were observed between prairies when measuring the number of tetracycline resistance genes present $(P=0.01)$. Of the 20 prairies, all were positive in the quantitative PCR assay for at least two different tetracycline resistance genes.

\section{Quantitative Polymerase Chain Reaction Assays}

Two genes, tet(A) and $\operatorname{sul}(\mathrm{I})$, were chosen for quantification using quantitative PCR. Bulk soil samples that were positive for these genes in the standard PCR assays were quantified. Results are reported in Table 2 . The number of copies in positive samples for each of the assayed genes varied both within and between

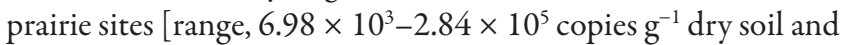
$9.63 \times 10^{2}-3.56 \times 10^{3}$ copies $\mathrm{g}^{-1}$ dry soil for tet $(\mathrm{A})$ and $\operatorname{sul}(\mathrm{I})$, respectively]. No correlations were observed between gene copy number and isolate phenotypic properties or between gene copy number and soil physical and chemical properties.

\section{Phenotypic Quantification}

Standard soil heterotrophic plate counts were performed on all samples and ranged from $3.5 \times 10^{4}$ to $1.8 \times 10^{7} \mathrm{CFU}$ per gram dry weight of soil, with the majority of samples $(n=76)$ containing counts in the $10^{5}$ range. Counts of soil bacteria on plates containing antibiotics ranged from $10^{2}$ to $10^{6}$ and from $10^{3}$ to $10^{6}$ for CR2A and TR2A, respectively. Soil heterotroph and cefotaxime-resistant heterotroph data were both negatively correlated with tetracycline resistance phenotype (Table 3). The percentage of isolates that were resistant to cefotaxime and tetracycline varied considerably within each prairie, with the tightest within-prairie counts being separated by $18 \%$ points. Despite this within-prairie variability, statistically significant differences were observed between prairies for plate count data (Table 4). For fecal indicators, 99 of the 100 samples were $<1$ CFU g ${ }^{-1}$ dry weight of soil for E. coli. As a reference, soil to which cattle feedlot runoff had been applied commonly had

\begin{tabular}{|c|c|c|c|c|c|c|c|c|c|c|c|c|c|c|c|c|c|c|c|c|c|c|}
\hline \multirow[b]{2}{*}{ Gene } & \multicolumn{20}{|c|}{ Prairie ID } & \multirow{2}{*}{$\begin{array}{c}\text { \# Positive } \\
\text { Samples }(n= \\
100)\end{array}$} & \multirow{2}{*}{$\begin{array}{l}\text { \# Prairies } \\
\text { Positive }(n \\
=20)\end{array}$} \\
\hline & 1 & 2 & 3 & 4 & 5 & 6 & 7 & 8 & 9 & 10 & 11 & 12 & 13 & 14 & 15 & 16 & 17 & 18 & 19 & 20 & & \\
\hline $\operatorname{tet}(\mathrm{A})$ & 3 & 2 & 2 & 2 & 4 & 2 & 4 & 0 & 5 & 2 & 4 & 2 & 3 & 4 & 0 & 3 & 2 & 3 & 1 & 4 & 52 & 18 \\
\hline $\operatorname{tet}(\mathrm{B})$ & 2 & 3 & 0 & 2 & 0 & 2 & 0 & 4 & 0 & 0 & 0 & 0 & 0 & 2 & 5 & 2 & 0 & 2 & 2 & 0 & 26 & 10 \\
\hline $\operatorname{tet}(\mathrm{C})$ & 0 & 0 & 1 & 1 & 1 & 0 & 0 & 0 & 0 & 2 & 1 & 1 & 1 & 2 & 0 & 1 & 0 & 0 & 3 & 0 & 14 & 10 \\
\hline $\operatorname{tet}(\mathrm{D})$ & 3 & 5 & 0 & 5 & 2 & 2 & 1 & 2 & 3 & 4 & 4 & 3 & 1 & 4 & 5 & 4 & 3 & 1 & 1 & 1 & 54 & 19 \\
\hline $\operatorname{tet}(\mathrm{E})$ & 1 & 0 & 0 & 0 & 0 & 1 & 0 & 0 & 3 & 1 & 0 & 0 & 1 & 1 & 2 & 0 & 1 & 2 & 1 & 1 & 15 & 11 \\
\hline $\operatorname{tet}(\mathrm{G})$ & 0 & 0 & 0 & 3 & 0 & 0 & 0 & 0 & 0 & 0 & 2 & 1 & 0 & 0 & 0 & 2 & 2 & 2 & 1 & 2 & 15 & 8 \\
\hline $\operatorname{tet}(\mathrm{K})$ & 0 & 1 & 0 & 3 & 0 & 0 & 0 & 0 & 1 & 2 & 0 & 0 & 0 & 0 & 0 & 0 & 0 & 1 & 0 & 0 & 8 & 5 \\
\hline $\operatorname{tet}(\mathrm{L})$ & 1 & 3 & 2 & 1 & 4 & 2 & 0 & 0 & 1 & 1 & 5 & 2 & 1 & 3 & 0 & 2 & 3 & 0 & 0 & 5 & 36 & 15 \\
\hline $\operatorname{tet}(\mathrm{M})$ & 0 & 1 & 0 & 0 & 0 & 0 & 1 & 1 & 0 & 0 & 0 & 4 & 1 & 0 & 1 & 0 & 4 & 0 & 0 & 1 & 14 & 8 \\
\hline $\operatorname{tet}(\mathrm{O})$ & 0 & 3 & 3 & 0 & 2 & 1 & 2 & 2 & 2 & 1 & 4 & 1 & 2 & 3 & 2 & 4 & 4 & 1 & 0 & 1 & 38 & 17 \\
\hline $\operatorname{tet}(\mathrm{Q})$ & 0 & 0 & 0 & 0 & 0 & 0 & 0 & 0 & 0 & 0 & 0 & 0 & 0 & 0 & 0 & 0 & 0 & 0 & 0 & 0 & 0 & 0 \\
\hline $\operatorname{tet}(\mathrm{S})$ & 0 & 0 & 0 & 0 & 0 & 2 & 1 & 0 & 0 & 0 & 0 & 0 & 0 & 0 & 4 & 1 & 0 & 0 & 4 & 0 & 12 & 5 \\
\hline $\operatorname{tet}(\mathrm{X})$ & 0 & 0 & 0 & 0 & 0 & 0 & 0 & 0 & 0 & 0 & 0 & 0 & 0 & 0 & 1 & 0 & 0 & 0 & 0 & 1 & 2 & 2 \\
\hline $\operatorname{tet} \mathrm{A}(\mathrm{P})$ & 1 & 0 & 0 & 0 & 0 & 1 & 0 & 0 & 0 & 1 & 0 & 1 & 2 & 3 & 2 & 0 & 2 & 1 & 0 & 2 & 16 & 10 \\
\hline $\operatorname{sul}(I)$ & 4 & 5 & 5 & 5 & 4 & 5 & 5 & 5 & 5 & 4 & 5 & 1 & 4 & 5 & 5 & 5 & 5 & 5 & 5 & 4 & 91 & 20 \\
\hline $\operatorname{sul(\mathrm {II})}$ & 0 & 1 & 2 & 2 & 1 & 2 & 1 & 1 & 0 & 2 & 1 & 0 & 2 & 3 & 1 & 0 & 0 & 0 & 2 & 0 & 21 & 13 \\
\hline
\end{tabular}

Fig. 1. Tetracycline and sulfonamide resistance genes detected in native Nebraska prairie soils. At each prairie site, samples were taken at five locations. Each result cell indicates the number of samples (of five total) that were positive for the listed gene. Red indicates all five samples at a prairie contained the assayed gene. Yellow and orange indicate one to four samples from the prairie contained the assayed gene. Green indicates none of the samples from that prairie were positive in our assay. 
Table 2. Quantitative polymerase chain reaction listed as average copies of the measured gene per gram dry soil. Values are an average of all positive samples from the indicated prairie.

\begin{tabular}{lcc}
\hline Prairie ID & tet(A) & sul(I) \\
\hline 1 & $3.23 \mathrm{E}+04$ & $1.89 \mathrm{E}+03$ \\
2 & $2.36 \mathrm{E}+04$ & $1.58 \mathrm{E}+03$ \\
3 & $1.63 \mathrm{E}+05$ & $2.17 \mathrm{E}+03$ \\
4 & $2.39 \mathrm{E}+04$ & $1.78 \mathrm{E}+03$ \\
5 & $8.58 \mathrm{E}+04$ & $1.47 \mathrm{E}+03$ \\
6 & $3.44 \mathrm{E}+04$ & $1.63 \mathrm{E}+03$ \\
7 & $1.27 \mathrm{E}+05$ & $1.72 \mathrm{E}+03$ \\
8 & $N \mathrm{ND}$ & $2.64 \mathrm{E}+03$ \\
9 & $1.28 \mathrm{E}+05$ & $1.83 \mathrm{E}+03$ \\
10 & $1.12 \mathrm{E}+05$ & $1.71 \mathrm{E}+03$ \\
11 & $1.14 \mathrm{E}+05$ & $1.61 \mathrm{E}+03$ \\
12 & $3.60 \mathrm{E}+04$ & $1.22 \mathrm{E}+03$ \\
13 & $7.39 \mathrm{E}+04$ & $1.81 \mathrm{E}+03$ \\
14 & $1.69 \mathrm{E}+04$ & $1.84 \mathrm{E}+03$ \\
15 & $N D$ & $1.94 \mathrm{E}+03$ \\
16 & $2.09 \mathrm{E}+04$ & $1.46 \mathrm{E}+03$ \\
17 & $1.05 \mathrm{E}+05$ & $1.78 \mathrm{E}+03$ \\
18 & $5.05 \mathrm{E}+04$ & $2.21 \mathrm{E}+03$ \\
19 & $1.97 \mathrm{E}+05$ & $1.97 \mathrm{E}+03$ \\
20 & $1.24 \mathrm{E}+05$ & $1.67 \mathrm{E}+03$ \\
\hline
\end{tabular}

† None detected.

$10^{3} \mathrm{CFU} \mathrm{g}{ }^{-1}$ dry weight $E$. coli (unpublished data). No statistically significant differences were observed between prairies for total coliform counts. However, differences were observed for Enterococcus counts.

\section{Disk Diffusion Assays}

For each of the 100 bulk soil samples, three isolates were picked off of nonselective plates and subjected to disk diffusion assays. Of these 300 isolates, five were lost during the freezing process, resulting in disk diffusion data for 295 isolates. Resistance, as defined using the CLSI standard methods and clinical breakpoints, was found to all 12 of the drugs tested (Table 5). On an isolate level, the drugs to which the fewest number of isolates displayed resistance were ciprofloxacin and kanamycin, each with $2 \%$ of the tested isolates displaying resistance. The drugs to which the largest number of isolates displayed resistance were ceftriaxone (43\%) and ampicillin (33\%). Of the tested isolates, only $7 \%$ displayed resistance to tetracycline using the standard CLSI definitions. All of the tested isolates were picked off of the nonselective R2A plates.
Had isolates been selected off of the R2A with tetracycline, it is possible that a higher proportion would have displayed clinical resistance. There were 72 isolates $(24 \%)$ that were resistant to a single antibiotic tested and $141(48 \%)$ that were resistant to two or more antibiotics tested. Examining the data on the prairie level, all 20 prairies had at least one isolate resistant to ceftriaxone and at least one isolate resistant to ampicillin. Nineteen of the 20 prairies had at least one isolate resistant to each cefoxitin and nalidixic acid. No statistically significant differences were observed between prairies for the number of phenotypic resistances displayed.

\section{Discussion}

Ungrazed native Nebraska prairie soils contain measurable amounts of antibiotic-resistant bacteria and AR genes. These results are consistent with other studies of AR in soils (Walsh and Duffy, 2013; Guardabassi and Agersø, 2006; Schmitt et al., 2006; Demanèche et al., 2008; Davelos et al., 2004) and are to be expected because antibiotic-resistant bacteria and their genes are a normal and natural part of soils (Cytryn, 2013; D'Costa et al., 2011; Finley et al., 2013). Of note is the high prevalence of sulfonamide resistance genes in the present study (91\%). The $\operatorname{sul}(\mathrm{I})$ gene concentrations measured were fairly consistent across prairies, in the range of $10^{3}$ copies per gram dry soil. Watershed studies have found the concentration of sulfonamide resistance genes to be correlated with human or animal antibiotic use, and the sul genes have been proposed as markers of anthropogenic AR gene pollution (Pruden et al., 2006). Data from this current prairie study suggest that sulfonamide resistance gene distributions may be different for land-based and water-based systems. However, because different methodologies were used, it is difficult to compare results directly. Furthermore, the microbial community structure of the soil differs considerably from the microbial community structure of fresh water streams and riverbeds. Because the Genes are correlated, to some degree with taxonomy (Durso et al., 2012), it is not surprising that a sample with a very different microbial community structure also has a different distribution of AR genes. The ungrazed native prairie sites examined in this study provided valuable information on background levels and types of AR that can be expected in southeastern Nebraskan soils in the absence of inputs from food animal agriculture.

The working hypothesis for this study was that geographically clustered ungrazed native Nebraska prairie soils would display similar levels and types of AR. More specifically,

Table 3. Correlation coefficientst of bacterial counts with selected phenotypic and genotypic measures of antibiotic resistance.

\begin{tabular}{lccr}
\hline Bacterial counts & Tetracycline resistance phenotype & Multidrug resistance phenotype & Tetracycline resistance genotype \\
\hline Total coliform $\neq$ & $0.06(0.52) \S$ & $-0.003(0.20)$ & $-\mathbf{0 . 2 5 * *}(0.01)$ \\
Enterococcus & $0.14(0.15)$ & $-0.15(0.13)$ & $0.11(0.30)$ \\
Soil heterotrophs & $-\mathbf{0 . 5 6 * *}(<0.0001)$ & $-0.05(0.65)$ & $-0.14(0.16)$ \\
Cefotaxime-resistant soil heterotrophs & $-\mathbf{0 . 3 3 * *}(0.0008)$ & $0.03(0.74)$ & $0.10(0.33)$ \\
Tetreacycline-resistant soil heterotrophs & NA & $0.15(0.12)$ & $-0.11(0.27)$ \\
\hline
\end{tabular}

** Significant at the 0.01 probability level.

*** Significant at the 0.001 probability level.

† A correlation coefficient is significant at the $95 \%$ level if $\mid$ correlation| $>0.197$ for $n=100$ (values in bold).

₹ Total coliforms includes some plant-associated bacteria.

$\S$ Values in parentheses represent the $\operatorname{Pr}>|r|$.

Journal of Environmental Quality 


\begin{tabular}{|c|c|c|c|c|c|}
\hline Prairie ID & Total coliforms & Enterococcus & $\mathrm{R} 2 \mathrm{~A}$ & CR2A & TR2A \\
\hline & & & og CFU g & & - \\
\hline 1 & 2.9at & $3.8 a$ & $5.1 \mathrm{bcd}$ & $4.8 \mathrm{bc}$ & $5.1 \mathrm{abcd}$ \\
\hline 2 & $3.5 a$ & $3.8 a$ & $5.2 \mathrm{abcd}$ & $4.8 a b c$ & 4.9abcd \\
\hline 3 & $4.0 a$ & $3.1 \mathrm{ab}$ & $5.9 a$ & $5.5 \mathrm{ab}$ & $5.6 a$ \\
\hline 4 & $3.8 a$ & $3.5 \mathrm{ab}$ & $5.7 a b c$ & $5.4 a b c$ & $5.4 a$ \\
\hline 5 & $4.2 \mathrm{a}$ & $3.2 \mathrm{ab}$ & 5.4abcd & $5.3 a b c$ & $5.4 a$ \\
\hline 6 & $4.0 a$ & $3.3 a b$ & $5.4 a b c d$ & $5.1 \mathrm{abc}$ & $5.0 \mathrm{ab}$ \\
\hline 7 & $3.6 a$ & $3.8 a$ & $5.7 a b$ & $5.6 a$ & $5.2 \mathrm{ab}$ \\
\hline 8 & $2.6 a$ & $3.1 \mathrm{ab}$ & $5.0 \mathrm{~cd}$ & $4.7 c$ & $5.3 a b$ \\
\hline 9 & $2.8 a$ & $2.8 a b$ & $5.0 \mathrm{bcd}$ & 4.9abc & $5.1 \mathrm{ab}$ \\
\hline 10 & $3.4 a$ & $2.8 a b$ & 5.4abcd & $5.2 \mathrm{abc}$ & $4.9 \mathrm{ab}$ \\
\hline 11 & $3.6 a$ & $2.8 a b$ & $5.2 \mathrm{bcd}$ & $4.9 a b c$ & $5.3 a$ \\
\hline 12 & $3.1 \mathrm{a}$ & $3.3 a b$ & $5.4 a b c d$ & $5.0 a b c$ & $5.3 a$ \\
\hline 13 & $3.6 a$ & $2.9 a b$ & $5.4 \mathrm{abcd}$ & $5.1 \mathrm{abc}$ & $4.9 a b$ \\
\hline 14 & $3.4 a$ & $3.4 a b$ & $5.3 \mathrm{abcd}$ & $5.2 \mathrm{abc}$ & $5.3 a b$ \\
\hline 15 & $2.2 a$ & $3.4 a b$ & $5.2 \mathrm{abcd}$ & $4.6 c$ & $5.0 a b$ \\
\hline 16 & $3.4 a$ & $3.3 a b$ & $5.0 \mathrm{~d}$ & $4.8 a b c$ & $5.2 \mathrm{ab}$ \\
\hline 17 & $2.3 a$ & $2.4 \mathrm{~b}$ & $5.0 \mathrm{~d}$ & $4.7 \mathrm{bc}$ & $4.9 a b$ \\
\hline 18 & $3.8 a$ & $3.4 a b$ & $5.2 \mathrm{abcd}$ & $5.0 a b c$ & $5.1 \mathrm{ab}$ \\
\hline 19 & $3.1 \mathrm{a}$ & $2.6 \mathrm{~b}$ & $5.5 \mathrm{abcd}$ & $5.2 \mathrm{abc}$ & $4.1 b$ \\
\hline 20 & $2.5 \mathrm{a}$ & $3.2 \mathrm{ab}$ & $5.2 \mathrm{abcd}$ & $4.9 a b c$ & $5.2 \mathrm{ab}$ \\
\hline LS SE $\neq$ & 0.4 & 0.2 & 0.1 & 0.2 & 0.2 \\
\hline
\end{tabular}

† Values followed by different letters differ $(p<0.05)$.

‡ Least squares standard error.

"similar" was defined for this study as (i) the trends for which individual soil samples have "more" resistance would be the same regardless of which phenotypic or genotypic measure of resistance was used and (ii) the absolute measurements of each AR parameter would be clustered around a central value, particularly within each prairie site. Although the results of this study provide some limited examples of similarity within and/ or between prairie sites, as a whole the data collected for 14 phenotypic and 19 genotypic measures of resistance assayed here do not support this hypothesis. Instead, the measurements reveal heterogeneity in baseline measures of AR between prairies and even among samples collected from the same prairies. Additionally, if "more resistance" is interpreted to mean a higher percentage of samples displaying the measured trait, then whether or not one prairie had more resistance than another depended on which phenotypic or genotypic assay was performed. For example, only half of the prairie sites $(n=10)$ were positive for tet $(B)$, compared with 19 of 20 positive prairie sites for $t e t(\mathrm{D})$. If resistance was defined as presence or absence of the tet $(B)$ gene, different conclusions would have been drawn about the prairie sites than if resistance was determined using only tet(D). Similarly, $100 \%$ of the soil samples from this study displayed tetracycline resistance, defined as bacterial colonies growing on an agar plate containing $16 \mu \mathrm{g} \mathrm{mL}^{-1}$ of tetracycline, but only $7 \%$ of the bacterial isolates from these same soils displayed resistance to tetracycline using the CLSI disk diffusion assay. As with other heterogeneous soil characteristics, phenotypic and genotypic AR measures can vary, even within

Table 5. Disk diffusion assay summary.

\begin{tabular}{|c|c|c|c|}
\hline Drug & Drug classification & $\begin{array}{l}\text { Percent resistant isolates } \\
\qquad(n=295)\end{array}$ & $\begin{array}{l}\text { Percent resistant prairies } \\
\qquad(n=20)\end{array}$ \\
\hline Amoxicillin with clavulanic acid & $\beta$-lactam (penicillin) and enzyme inhibitor & 16 & 85 \\
\hline Ampicillin & $\beta$-lactam (penicillin) & 33 & 100 \\
\hline Cefoxitin & $\beta$-lactam (2GC +$)$ & 27 & 95 \\
\hline Ceftriaxone & $\beta$-lactam (3GC $\ddagger)$ & 43 & 100 \\
\hline Chloramphenicol & amphenicol & 10 & 70 \\
\hline Ciprofloxacin & fluoroquinolone & 2 & 30 \\
\hline Gentamicin & aminoglycoside & 10 & 80 \\
\hline Kanamycin & aminoglycoside & 2 & 25 \\
\hline Nalidixic acid & quinolone & 21 & 95 \\
\hline Streptomycin & aminoglycoside & 14 & 85 \\
\hline Tetracycline & tetracycline & 7 & 50 \\
\hline Sulfamethoxazole + trimethoprim & sulfonomide + enzyme inhibitor & 12 & 70 \\
\hline
\end{tabular}

† Second-generation cephalosporin.

‡ Third-generation cephalosporin. 
a fairly restricted space and time. The data collected in this study provide information on the range of values that can be expected in unaffected Nebraska soils. The variety observed in the measured parameters supports pooling of samples and the use of multiple measurement parameters (Singer and WilliamsNguyen, 2014) when evaluating AR in manure-affected soils.

\section{Measuring Antibiotic Resistance in Agriculture}

Although a common goal is to reduce AR on farms and in feedlots (Finley et al., 2013), there is little available evidence to help decide what a realistic target would be for reduction. Knowing what kinds and amounts of resistance are in native prairie soils will help to determine the kinds and amounts of resistance that can be affected by agricultural best management practices (agBMPs) (Singer and Williams-Nguyen, 2014) in other southeastern Nebraska soils. With over 4570 cattle feeding operations in Nebraska, it is common to apply cattle manure to the soil. Ideally, data on background levels of AR will be gathered for each of the specific AR parameters being assayed in manure-affected soils. Knowing that over $70 \%$ of the 300 isolates collected here from minimally affected soils display resistance (as defined by CLSI disk diffusion assay), with almost half (48\%) being multidrug resistant (31\% if "multidrug resistant" is defined as resistance to three or more drugs) can help to put into perspective the numbers coming out of studies in agricultural production systems. When setting targets for reduction, it is unlikely that agBMPs can reduce resistance below the background levels.

If it is not possible or practical to collect background data from minimally affected sites such as ungrazed prairies or forest soils (Storteboom et al., 2010; Popowska et al., 2012; Shange et al., 2012), the next best option would be to collect baseline data (i.e., from the soils before manure application) (Cook et al., 2014; McLain and Williams, 2014; Marti et al., 2014) so that it is possible to separate out the types of resistance that are most relevant to agricultural production and human health (Durso and Cook, 2014; Wittum, 2012; Phillips et al., 2004). One question that arises from this study is: When examining AR in agricultural soils, does naturally occurring resistance present the same risks to human health as resistance that has been enriched by the administration of drugs to food animals (Martínez et al., 2015)? In one study, prairie soils were found to have more $\beta$-lactamase genes than cultivated fields (Demanèche et al., 2008). Data from the current study reveal widespread phenotypic and genotypic resistance. On a practical level, when developing strategies to minimize the transfer of AR from agroecosystems, we argue that it does not matter whether the resistance was naturally occurring, as in this study, or enriched due to human use.

A common assumption regarding the use of antibiotics in agriculture is that reduced administration of antibiotics to food animals will result in a decrease of AR in the animal feces, leading to a decreased risk to human health (Singer et al., 2003; Marshall and Levy, 2011). However, recent data reveal that feces, even from antibiotic-free animals, can carry multiple types of resistance and enrich for AR in the soil (Udikovic-Kolic et al., 2014; Zhou et al., 2009; Kyselková et al., 2013; Schmitt et al., 2006). Thus, studies in unaffected sites that are not receiving manure inputs provide a unique insight into the background types and distributions of AR in local agricultural soils.

\section{Ecology of Resistance in Nebraskan Soils}

When discussing AR in the environment, it is common to equate resistance not only with antibiotic-resistant bacteria but also with the presence or absence of particular AR genes (Zhang et al., 2013; Martínez et al., 2015; Storteboom et al., 2010; Durso et al., 2011). We looked for correlations between phenotypic and genotypic measures of resistance and common soil physical and chemical parameters but did not identify any relationships between abiotic drivers of microbial communities and the selected measures of antibiotic-resistant bacteria or AR genes. Metagenomic studies of bacterial diversity and function in preagricultural prairie soils also found no links between soil variables and bacterial taxonomy (Fierer et al., 2013).

One shortcoming of environmental studies of AR, including this study, is that "resistance" is commonly defined using clinical terms, which may or may not accurately reflect the relationships and dynamics of environmental isolates or soil communities (Walsh and Duffy, 2013). For example, in this study the CLSI standard methods for disk diffusion assays were used, including using the CLSI interpretive criteria for assigning "resistant," "intermediate," or "sensitive" status for each data point. In clinical settings, these categories are linked to the ecology of infectious disease, with "resistance" being strongly correlated with clinical treatment failure (Jorgenses and Ferraro, 2009). The use of a term with environmental isolates or communities implies a threat equivalent to resistance in clinical settings. However, resistance is not generally defined for environmental isolates (Berendonk et al., 2015).

\section{Conclusions}

Data from ungrazed Nebraska prairie soils indicate an inherent heterogeneity in natural soils for both phenotypic and genotypic measurements of AR. Resistant bacteria and resistance genes are common, even in native prairie soils with no inputs from domesticated food animals. To sort out the contributions of food-animal antibiotic use on resistance at farms and in the environment, it is therefore essential that background and/or baseline levels of AR be considered and acknowledged when evaluating $A R$ in agroecosystems. Data from agriculturally affected sites must be evaluated in the larger context of naturally occurring levels of resistance for individual production systems and soil types.

Reducing AR in agroecosystems, especially food animal production systems, is an important issue. Data from this study, demonstrating AR occurring naturally in the soil and advocating that assessments of resistance on farms and in manure-affected environments include the collection of background and/or baseline data, do not minimize the importance of identifying, evaluating, and adopting agBMPs that reduce AR in agricultural production systems. Instead, these applied data can be used to more accurately assess the impacts of individual agBMPs on specific measures of AR, allowing us to focus limited resources where they will have the most impact. 


\section{Acknowledgments}

The authors thank Jennifer McGhee, Jaime LaBrie, Amy Mantz, Angel Iverson, Katherine Herman, and Emily Hubl for laboratory and field support; Sara Murray, Ryan McGhee, Aaron Bereuter, Tyler Hoehn, and Tyler Goeschel for assistance in collecting samples; and Paul Koerner and Myron Coleman for additional technical support. We also extend our sincere thanks to the land owners and managers for maintaining the prairie sites and allowing us to collect samples. This work was funded by USDA-ARS National Program 214, Agricultural and Industrial Byproduct Utilization, now part of National Program 212 Soil and Air Research Program.

\section{References}

Allen, H.K., J. Donato, H.H. Wang, K.A. Cloud-Hansen, J. Davies, and J. Handelsman. 2010. Call of the wild: Antibiotic resistance genes in natural environments. Nat. Rev. Microbiol. 8:251-259. doi:10.1038/nrmicro2312

Amos, G.C.A., E. Gozzard, C.E. Carter, A. Mead, M.J. Bowes, P.M. Hawkey, L. Zhang, A.C. Singer, W.H. Gaze, and E.M.H. Wellington. 2015. Validated predictive modelling of the environmental resistome. ISME J. 9:1476. doi:10.1038/ismej.2014.237

Ashbolt, N.J., A. Amézquita, T. Backhaus, P. Borriello, K.K. Brandt, P. Collignon, A. Coors, R. Finley, W.H. Gaze, T. Heberer, J.R. Lawrence, D.G.J. Larsson, S.A. McEwen, J.J. Ryan, J. Schönfeld, P. Silley, J.R. Snape, C. Van den Eede, and E. Topp. 2013. Human health risk assessment (HHRA) for environmental development and transfer of antibiotic resistance. Environ. Health Perspect. 121:993-1001.

Berendonk, T.U., C.M. Manaia, C. Merlin, D. Fatta-Kassinos, E. Cytryn, F. Walsh, H. Bürgmann, H. Sørum, M. Norström, M. Pons, N. Kreuzinger, P. Huovinen, S. Stefani, T. Schwarts, V. Kisand, F. Baquero, and J.L. Martínez. 2015. Tackling antibiotic resistance: The environmental framework. Nat. Rev. Microbiol. 13:310-317. doi:10.1038/nrmicro3439

Böckelmann, U., H. Dörries, M.N. Ayuso-Gabella, M. Salgot de Marçay, V. Tandori, C. Levantesi, C. Mascioppinto, E. Van Houtte, U. Szewzyk, T. Wintgens, and E. Grohmann. 2009. Quantitative PCR monitoring of antibiotic resistance genes and bacterial pathogens in three European artificial groundwater recharge systems. Appl. Environ. Microbiol. 75:154-163. doi:10.1128/AEM.01649-08

Chen, J., Z. Yu, F.C. Michel, Jr., T. Wittum, and M. Morrison. 2007. Development and application of real-time PCR assays for quantification of erm genes conferring resistance to macrolides-lincosamides-streptogramin B in livestock manure and manure management systems. Appl. Environ. Microbiol. 73:4407-4416. doi:10.1128/AEM.02799-06

Clinical and Laboratory Standards Institute. 2012. Performance standards for antibiotic disk susceptibility tests: Approved standard. Eleventh ed. CLSI, Wayne, PA.

Cook, K.L., A.M.P. Netthisinghe, and R.A. Gilfillen. 2014. Detection of pathogens, indicators, and antibiotic resistance genes after land application of poultry litter. J. Environ. Qual. 43:1546-1558. doi:10.2134/ jeq2013.10.0432

Cottell, J.L., N. Kanwar, L. Castillo-Courtade, G. Chalmers, H.M. Scott, B. Norby, G.H. Loneragan, and P. Boerlin. 2013. Blactx-M-32 on and incN plasmid in Escherichia coli from beef cattle in the United States. Appl. Environ. Microbiol. 57:1096-1097.

Cytryn, E. 2013. The soil resistome: The anthropogenic, the native, and the unknown. Soil Biol. Biochem. 63:18-23. doi:10.1016/j.soilbio.2013.03.017

D'Costa, V.M., K.M. McGrann, D.W. Hughes, and G.D. Wright. 2006. Sampling the antibiotic resistome. Science 311:374-377. doi:10.1126/ science. 1120800

D'Costa, V.M., E. Griffiths, and G.D. Wright. 2007. Expanding the soil antibiotic resistome: Exploring environmental diversity. Curr. Opin. Microbiol. 10:481-489. doi:10.1016/j.mib.2007.08.009

D’Costa, V.M., C.E. King, L. Kalan, M. Morar, W.W.L. Sung, C. Schwarz, D. Froese, G. Zazula, F. Camels, R. Debruyne, G.B. Golding, H.N. Poinar, and G.D. Wright. 2011. Antibiotic resistance in ancient. Nature 477:457461. doi: $10.1038 /$ nature 10388

Davelos, A.L., L.L. Kinkel, and D.A. Samac. 2004. Spatial variation in frequency and intensity of antibiotic interactions among Streptomycetes from prairie soil. Appl. Environ. Microbiol. 70:1051-1058. doi:10.1128/ AEM.70.2.1051-1058.2004

Demanèche, S., H. Sanguin, J. Poté, E. Navarro, D. Bernillon, P. Mavingui, W. Wildi, T.M. Vogel, and P. Simonet. 2008. Antibiotic-resistant soil bacteria in transgenic plant fields. Proc. Natl. Acad. Sci. USA 105:3957-3962. doi: $10.1073 /$ pnas. 0800072105
Durso, L.M., G.P. Harhay, J.L. Bono, and T.P. Smith. 2011. Virulence-associated and antibiotic resistance genes of microbial populations in cattle feces analyzed using a metagenomic approach. J. Microbiol. Methods 84:278-282. doi:10.1016/j.mimet.2010.12.008

Durso, L.M., D.N. Miller, and B.J. Wienhold. 2012. Distribution and quantification of antibiotic resistant genes and bacteria across agricultural and nonagricultural metagenomes. PLoS One 7:e48325. doi:10.1371/journal. pone. 0048325

Durso, L.M., and K.L. Cook. 2014. Impacts of antibiotic use in agriculture: What are the benefits and risks? Curr. Opin. Microbiol. 19:37-44. doi:10.1016/j.mib.2014.05.019

Fey, P.D., T.J. Safranek, M.E. Rupp, E.F. Dunne, E. Ribot, P.C. Iwen, P.A. Bradford, F.J. Angulo, and S.H. Hinrichs. 2000. Ceftriaxone-resistant Salmonella infection acquired by a child from cattle. N. Engl. J. Med. 342:12421249. doi:10.1056/NEJM200004273421703

Fierer, N., J. Ladau, J.C. Clemente, J.W. Leff, S.M. Owens, K.S. Pollard, R. Knight, J.A. Gilbert, and R.L. McCulley. 2013. Reconstructing the microbial diversity and function of pre-agricultural tallgrass prairie soils in the United States. Science 342:621-624. doi:10.1126/science.1243768

Finley, R.L., P. Collignon, D.G.J. Larsson, S.A. McEwen, X. Li, W. Hl Gaze, R. Reid-Smith, M. Timinouni, D.W. Graham, and E. Topp. 2013. The scourge of antibiotic resistance: The important role of the environment. Clin. Infect. Dis. 57:704-710. doi:10.1093/cid/cit355

Fosberg, K.J., A. Reyes, B. Wang, E.M. Selleck, M.O.A. Sommer, and G. Dantas. 2012. The shared antibiotic resistome of soil bacteria and human pathogens. Science 337:1107-1111. doi:10.1126/science.1220761

Gilchrist, J.E., J.E. Campbell, C.B. Donnelly, J.T. Peeler, and J.M. Delaney. 1973. Spiral plate method for bacterial determination. Appl. Environ. Microbiol. 25:244-252.

Guardabassi, L., and Y. Agersø. 2006. Genes homologous to glycopeptides resistance van A are widespread in soil microbial communities. FEMS Microbiol. Lett. 259:221-225. doi:10.1111/j.1574-6968.2006.00270.x

Jorgenses, J.H., and M.J. Ferraro. 2009. Antimicrobial susceptibility testing: A review of general principles and contemporary practices. Clin. Infect. Dis. 49:1749-1755. doi:10.1086/647952

Koh, T.H., K. Ko, R. Jureen, R.N. Deepak, N.W.S. Tee, T.Y. Tan, M. Rong, J. Tay, V.J.M. Lee, and T.M.S. Barkham. 2015. High counts of carbapenemaseproducing Enterobacteriaceae in hospital sewage. Infect. Control Hosp. Epidemiol. 36:619-621. doi:10.1017/ice.2015.44

Kozak, G.K., P. Boerlin, N. Janecko, R.J. Reid-Smith, and C. Jardine. 2009. Antimicrobial resistance in Escherichia coli isolates from swine and wild small mammals in the proximity of swine farms and in natural environments in Ontario, Canada. Appl. Environ. Microbiol. 75:559-566. doi:10.1128/ AEM.01821-08

Kyselková, M., J. Jirout, A. Chroňáková, N. Vrchotová, R. Bradley, H. Schmitt, and D. Elhottová. 2013. Cow excrements enhance the occurrence of tetracycline resistance genes in soil regardless of their oxytetracycline content. Chemosphere 93:2413-2418. doi:10.1016/j. chemosphere.2013.08.058

Marshall, B.M., and S.B. Levy. 2011. Food animals and antimicrobials: Impacts on human health. Clin. Microbiol. Rev. 24:718-733. doi:10.1128/ CMR.00002-11

Marti, R., Y. Tien, R. Murray, A. Scott, L. Sabourin, and E. Topp. 2014. Safely coupling livestock and crop production systems: How rapidly do antibiotic resistance genes dissipate in soil following a commercial application of swine or dairy manure? Appl. Environ. Microbiol. 80:3258-3265. doi:10.1128/AEM.00231-14

Martínez, J.L., T.M. Coque, and F. Baquero. 2015. What is a resistance gene? Ranking risk in resistomes. Nat. Rev. Microbiol. 13:116-123. doi:10.1038/ nrmicro3399

McLain, J.E., and C.F. Williams. 2014. Sustainability of water reclamations: Long-term recharge with reclaimed wastewater does not enhance antibiotic resistance in sediment bacteria. Sustainability 6:1313-1327. doi: $10.3390 /$ su6031313

Ng, L.K., I. Martin, M. Alfa, and M. Mulvey. 2001. Multiplex PCR for the detection of tetracycline resistant genes. Mol. Cell. Probes 15:209-215. doi: $10.1006 / \mathrm{mcpr} .2001 .0363$

Pei, R., K. Sung-Chul, K.H. Carlson, and A. Pruden. 2006. Effect of river landscape on the sediment concentrations of antibiotics and corresponding antibiotic resistance genes (ARG). Water Res. 40:2427-2435. doi:10.1016/j. watres.2006.04.017

Phillips, I., M. Casewell, T. Cox, B. DeGroot, C. Friis, R. Jones, C. Nightengale, R. Preston, and J. Waddell. 2004. Does the use of antibiotics in food animals pose a risk to human health? A critical review of published data. J. Antimicrob. Chemother. 53:28-52. doi:10.1093/jac/ dkg483 
Popowska, M., M. Rzeczycka, A. Miernik, A. Krawczyk-Balska, F. Walsh, and B. Duffy. 2012. Influence of soil use on prevalence of tetracycline, streptomycin, and erythromycin resistance and associated resistance genes. Antimicrob. Agents Chemother. 56:1434-1443. doi:10.1128/ AAC.05766-11

Pruden, A., R. Pei, H. Storetboom, and K.H. Carlson. 2006. Antibiotic resistance genes as emerging contaminants: Studies in northern Colorado. Environ. Sci. Technol. 40:7445-7450. doi:10.1021/es0604131

Rutgersson, C., J. Fick, N. Marathe, E. Kristiansson, A. Janzon, M. Angelin, A. Johansson, Y. Souche, C.F. Flach, and D.G. Larsson. 2014. Fluoroquinolones and qnr genes in sediment, water, soil, and human fecal flora in an environment polluted by manufacturing discharges. Environ. Sci. Technol. 48:7825-7832. doi:10.1021/es501452a

SAS Institute. 2008. The SAS system for Windows. Release 9.2. SAS Inst., Cary, NC.

Schmitt, H., K. Stoob, G. Hamscher, E. Smit, and W. Seinen. 2006. Tetracyclines and tetracycline resistance in agricultural soils: Microcosm and field studies. Microb. Ecol. 51:267-276. doi:10.1007/s00248-006-9035-y

Shange, R.S., R.O. Ankumah, A.M. Ibekwe, R. Zabawa, and S.E. Dowd. 2012. Distinct soil bacterial communities revealed under a diversely managed acroecosystem. PLoS One 7:e40338. doi:10.1371/journal.pone.0040338

Singer, R.S., R. Finch, H.C. Wegener, R. Bywater, J. Walters, and M. Lipstitch. 2003. Antibiotic resistance: The interplay between antibiotic use in animals and human beings. Lancet Infect. Dis. 3:47-51. doi:10.1016/ S1473-3099(03)00490-0

Singer, R.S., and J. Williams-Nguyen. 2014. Human health impacts of antibiotic use in agriculture: A push for improved causal inference. Curr. Opin. Microbiol. 19:1-8. doi:10.1016/j.mib.2014.05.014

Storteboom, H., M. Arabi, J.G. Davis, B. Crimi, and A. Pruden. 2010. Tracking antibiotic resistance genes in the South Platte River Basin using molecular signatures of urban, agricultural, and pristine sources. Environ. Sci. Technol. 44:7397-7404. doi:10.1021/es101657s
Udikovic-Kolic, N., F. Wichmann, N.A. Broderick, and J. Handelsman. 2014. Bloom of resident antibiotic-resistant bacteria in soil following manure fertilization. Proc. Natl. Acad. Sci. USA 111:15202-15207. doi:10.1073/ pnas. 1409836111

USDA National Statistics Service. 2012. Census of agriculture, Volume 1, Geographic Area Series, Part 21, Chapter 1: State level data (Nebraska). AC12-A-27. USDA, Washington, DC.

Walsh, F., and B. Duffy. 2013. The culturable soil antibiotic resistome: A community of multi-drug resistant bacteria. PLoS One 8:e65567. doi:10.1371/ journal.pone.0065567

Williams-Nguyen, J., J.B. Sallach, S. Bartelt-Hunt, A.B. Boxall, L.M. Durso, J.E. McLain, R.S. Singer, D.D. Snow, and J.L. Ziles. 2015. Antibiotics and antibiotic resistance in agroecosystems: State of the science. J. Environ. Qual. (in press).

Wittum, T.E. 2012. The challenge of regulating agricultural ceftiofur use to slow the emergence of resistance to extended-spectrum cephalosporins. Appl. Environ. Microbiol. 78:7819-7821. doi:10.1128/AEM.01967-12

Wright, G.D. 2010. Antibiotic resistance in the environment: A link to the clinic? Curr. Opin. Microbiol. 13:589-594. doi:10.1016/j.mib.2010.08.005

Zhang, Y., D.D. Snow, D. Parker, Z. Zhou, and X. Li. 2013. Intracellular and extracellular antimicrobial resistance genes in the sludge of livestock waste management structures. Environ. Sci. Technol. 47:10206-10213.

Zhou, Z., L. Raskin, and J.L. Zilles. 2009. Macrolide resistance in microorganisms at antimicrobial-free swine farm. Appl. Environ. Microbiol. 75:5814-5820. 
Assessment of Selected Antibiotic Resistances in Ungrazed Native Nebraska Prairie Soils

Supplementary Figure 1. Prairie sites. Shaded counties indicate areas from which samples were collected. Counties, listed from north to south, are Lancaster, Otoe, Johnson, Pawnee, and Richardson.

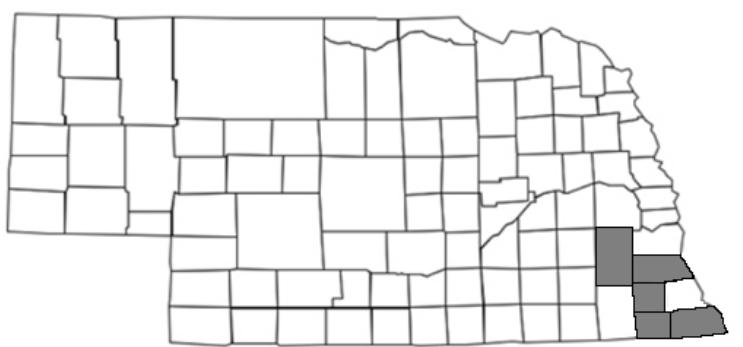


Assessment of Selected Antibiotic Resistances in Ungrazed Native Nebraska Prairie Soils Table S1: PCR Primers

Contact person: Lisa Durso lisa.durso@ars.usda.gov

Table S1. Primers used in study.

\begin{tabular}{|c|c|c|c|c|}
\hline Primer Name & Sequence & $\begin{array}{l}\text { Length } \\
\text { (bp) }\end{array}$ & $\mathrm{TM}\left({ }^{\circ} \mathrm{C}\right)$ & $\begin{array}{l}\text { Product } \\
\text { size (bp) }\end{array}$ \\
\hline $\mathrm{Ng} \operatorname{tet}(\mathrm{A}) \mathrm{F}+$ & 5'-GCT ACA TCC TGC TTG CCT TC $-3^{\prime}$ & 20 & 63.8 & 210 \\
\hline $\mathrm{Ng}$ tet $(\mathrm{A}) \mathrm{R}^{+}$ & 5'-CAT AGA TCG CCG TGA AGA GG -3' & 20 & 64.6 & \\
\hline $\mathrm{Ng}$ tet(B) $\mathrm{F}^{\dagger}$ & $5^{\prime}$-TTG GTT AGG GGC AAG TTT TG $-3^{\prime}$ & 20 & 63.6 & 659 \\
\hline $\mathrm{Ng}$ tet(B) $\mathrm{R}^{\dagger}$ & 5'-GTA ATG GGC CAA TAA CAC CG -3' & 20 & 63.7 & \\
\hline $\mathrm{Ng} \operatorname{tet}(\mathrm{C}) \mathrm{F}^{\dagger}$ & 5'-CTT GAG AGC CTT CAA CCC AG -3' & 20 & 63.8 & 418 \\
\hline $\mathrm{Ng}$ tet $(\mathrm{C}) \mathrm{R}^{\dagger}$ & 5'-ATG GTC GTC ATC TAC CTG CC - $3^{\prime}$ & 20 & 63.9 & \\
\hline $\mathrm{Ng}$ tet(D) F† & 5'-AAA CCA TTA CGG CAT TCT GC - $3^{\prime}$ & 20 & 63.6 & 787 \\
\hline $\mathrm{Ng}$ tet(D) $\mathrm{R}^{\dagger}$ & $5^{\prime}-$ GAC CGG ATA CAC CAT CCA TC $-3^{\prime}$ & 20 & 64.0 & \\
\hline $\mathrm{Ng}$ tet $(\mathrm{E}) \mathrm{F}+$ & 5'-AAA CCA CAT CCT CCA TAC GC - $3^{\prime}$ & 20 & 63.6 & 278 \\
\hline $\mathrm{Ng}$ tet $(\mathrm{E}) \mathrm{R}^{\dagger}$ & 5'-AAA TAG GCC ACA ACC GTC AG -3' & 20 & 63.7 & \\
\hline $\mathrm{Ng} \operatorname{tet}(\mathrm{G}) \mathrm{F}+$ & 5'-CAG CTT TCG GAT TCT TAC GG -3' & 20 & 63.5 & 844 \\
\hline $\mathrm{Ng}$ tet(G) $\mathrm{R}^{\dagger}$ & 5'-GAT TGG TGA GGC TCG TTA GC $-3^{\prime}$ & 20 & 63.6 & \\
\hline $\mathrm{Ng}$ tet $(\mathrm{K}) \mathrm{F}^{+}$ & 5'-TCG ATA GGA ACA GCA GTA -3' & 18 & 54.0 & 169 \\
\hline $\mathrm{Ng} \operatorname{tet}(\mathrm{K}) \mathrm{R}^{\dagger}$ & 5'-CAG CAG ATC CTA CTC CTT -3' & 18 & 54.1 & \\
\hline $\mathrm{Ng}$ tet $(\mathrm{L}) \mathrm{F}^{+}$ & 5'-TCG TTA GCG TGC TGT CAT TC $-3^{\prime}$ & 20 & 63.9 & 267 \\
\hline $\mathrm{Ng}$ tet $(\mathrm{L}) \mathrm{R}^{\dagger}$ & 5'-GTA TCC CAC CAA TGT AGC CG -3' & 20 & 64.0 & \\
\hline $\mathrm{Ng}$ tet $(\mathrm{M}) \mathrm{F}+$ & 5'-GTG GAC AAA GGT ACA ACG AG -3' & 20 & 59.6 & 406 \\
\hline $\mathrm{Ng}$ tet $(\mathrm{M}) \mathrm{R}^{\dagger}$ & $5^{\prime}-$ CGG TAA AGT TCG TCA CAC AC - $3^{\prime}$ & 20 & 60.6 & \\
\hline $\mathrm{Ng}$ tet(O) $\mathrm{F}^{\dagger}$ & 5'-AAC TTA GGC ATT CTG GCT CAC - $3^{\prime}$ & 21 & 62.1 & 515 \\
\hline $\mathrm{Ng} \operatorname{tet}(\mathrm{O}) \mathrm{R}+$ & 5'-TCC CAC TGT TCC ATA TCG TCA -3' & 21 & 65.2 & \\
\hline $\mathrm{Ng}$ tet $(\mathrm{Q}) \mathrm{F}^{+}$ & 5'-TTA TAC TTC CTC CGG CAT CG -3' & 20 & 63.7 & 904 \\
\hline $\mathrm{Ng}$ tet(Q) $\mathrm{R}^{\dagger}$ & 5'-ATC GGT TCG AGA ATG TCC AC -3' & 20 & 63.9 & \\
\hline $\mathrm{Ng}$ tet $(\mathrm{S}) \mathrm{F}^{+}$ & 5'-CAT AGA CAA GCC GTT GAC C - $3^{\prime}$ & 19 & 60.7 & 667 \\
\hline $\mathrm{Ng}$ tet $(\mathrm{S}) \mathrm{R}^{\dagger}$ & 5'-ATG TTT TTG GAA CGC CAG AG -3' & 20 & 63.8 & \\
\hline $\mathrm{Ng}$ tet $(\mathrm{X}) \mathrm{F}^{\dagger}$ & 5'-CAA TAA TTG GTG GTG GAC CC $-3^{\prime}$ & 20 & 63.7 & 468 \\
\hline $\mathrm{Ng}$ tet $(\mathrm{X}) \mathrm{R}^{\dagger}$ & 5'-TTC TTA CCT TGG ACA TCC CG -3' & 20 & 63.7 & \\
\hline $\mathrm{Ng} \operatorname{tet} A(\mathrm{P}) \mathrm{F}^{\dagger}$ & 5'-CTT GGA TTG CGG AAG AAG AG -3' & 20 & 63.7 & 676 \\
\hline $\mathrm{Ng} \operatorname{tet} A(\mathrm{P}) \mathrm{R}+$ & 5'-ATA TGC CCA TTT AAC CAC GC -3' & 20 & 63.3 & \\
\hline Pei sul(I) F & 5'-CGC ACC GGA AAC ATC GCT GCA C-3' & 22 & 63.8 & 163 \\
\hline Pei sul(I) R & 5'-TGA AGT TCC GCC GCA AGG CTC G-3' & 22 & 64.6 & \\
\hline Pei sul(II) F & 5'-TCC GGT GGA GGC CGG TAT CTG G-3' & 22 & 65.1 & 191 \\
\hline Pei sul(II) R $¥$ & 5'-CGG GAA TGC CAT CTG CCT TGA G-3' & 22 & 60.6 & \\
\hline Böckelmann erm(B) F§ & 5'- GCA TTT AAC GAC GAA ACT GGC T -3' & 22 & 56.2 & 573 \\
\hline Böckelmann erm(B) R§ 5 & '-GAC AAT ACT TGC TCA TAA GTA ATG GT-3' & 26 & 53.2 & \\
\hline Chen $\operatorname{erm}(\mathrm{B}) \mathrm{Fq}$ & 5'-GAT ACC GTT TAC GAA ATT GG-3' & 20 & 49.0 & 364 \\
\hline Chen erm(B)Rף & 5'-GAA TCG AGA CTT GAG TGT GC-3' & 20 & 53.4 & \\
\hline Kozak CMY-2 F\# & 5'-GAC AGC CTC TTT CTC CAC A-3' & 19 & 54.3 & 1015 \\
\hline Kozak CMY-2 R\# & 5'-TGG AAC GAA GGC TAC GTA-3' & 18 & 52.9 & \\
\hline Cottell CTX-M F†† & 5'-CCG CTG CCG GTY TTA TC-3' & 17 & 55.1 & $490-520$ \\
\hline Cottell CTX-M R+† & 5'-ATG TGC AGY ACC AGT AA-3' & 17 & 49.3 & \\
\hline
\end{tabular}


† Ng, L.K., I. Martin, M. Alfa, and M. Mulvey. 2001. Multiplex PCR for the detection of tetracycline resistant genes. Mol. Cell. Probes. 15:209-215.

¥ Pei, R., K. Sung-Chul, K.H. Carlson, and A. Pruden. 2006. Effect of River Landscape on the sediment concentrations of antibiotics and corresponding antibiotic resistance genes (ARG). Water Res. 40:24272435.

$\S$ Böckelmann, U., H. Dörries, M.N. Ayuso-Gabella, M. Salgot de Marçay, V. Tandori, C. Levantesi, C. Mascioppinto, E. Van Houtte, U. Szewzyk, T. Wintgens, and E. Grohmann. 2009. Quantitative PCR Monitoring of Antibiotic Resistance Genes and Bacterial Pathogens in Three European Artificial Groundwater Recharge Systems. Appl. Environ. Microb. 75:154-163.

I Chen, J., Z. Yu, F.C. Michel, Jr., T. Wittum, and M. Morrison. 2007. Development and application of real-time PCR assays for quantification of erm genes conferring resistance to macrolides- lincosamidesstreptogramin B in livestock manure and manure management systems. Appl. Environ. Microb. 73:4407-4416.

\# Kozak, G.K., P. Boerlin, N. Janecko, R.J. Reid-Smith, and C. Jardine. 2009. Antimicrobial resistance in Escherichia coli isolates from swine and wild small mammals in the proximity of swine farms and in Natural Environments in Ontario, Canada. Appl Environ Microbiol. 75:559-566.

†† Cottell, J.L., N. Kanwar, L.Castillo-Courtade, G. Chalmers, H.M. Scott, B. Norby, G.H. Loneragan, and P. Boerlin. 2013. Blactx-M-32 on and incN plasmid in Eschericia coli from beef cattle in the United States. Appl Environ Microbiol. 57:10-96-1097. 


\section{Assessment of Selected Antibiotic Resistances in Ungrazed Native Nebraska Prairie Soils}

\section{Table S2: PCR Recipes and Thermocycling Conditions}

Contact person: Lisa Durso lisa.durso@ars.usda.gov

\section{Qualitative PCR}

\begin{tabular}{|c|c|c|c|c|}
\hline Resistance & Genes & PCR Recipe Used & Themocycling Conditions Used & Reference \\
\hline Tetracycline & $\begin{array}{l}A, B, C, D, E, G, K \\
L, M, O, Q, S, X \\
A(P)\end{array}$ & $\begin{array}{l}12.5 \mu \text { l of Jumpstart Red Taq was combined with } 0.5 \mu \mathrm{l} \text { of } \\
\text { each primer (100mM), } 1 \mu \text { l of extracted DNA, and reagent } \\
\text { grade water to bring the total reaction volume to } 25 \mu \mathrm{l} \text {. }\end{array}$ & $\begin{array}{l}1 \mathrm{cycle} \text { of } 94^{\circ} \mathrm{C} \text { for } 5 \mathrm{~min} ; 35 \text { cycles of } 94^{\circ} \mathrm{C} \text { for } 1 \mathrm{~min}, 55^{\circ} \mathrm{C} \\
\text { for } 1 \mathrm{~min} \text { and } 72^{\circ} \mathrm{C} \text { for } 90 \text { seconds; and one cycle of } 72^{\circ} \mathrm{C} \\
\text { for } 5 \text { minutes. }\end{array}$ & Ng et al. 2001 \\
\hline \multirow[t]{2}{*}{ Sulfonamide } & $\operatorname{sul}(\mathrm{I})$ & $\begin{array}{l}9 \mu \mathrm{l} \text { of } 5 \text { PrimeMasterMix (5Prime, Gaithersburg MD), } 0.4 \mu \mathrm{l} \\
\text { of each primer (100mM), } 1 \mu \mathrm{l} \text { of template DNA, and reagent- } \\
\text { grade water in a final reaction volume of } 20 \mu \mathrm{l} .\end{array}$ & $\begin{array}{l}\text { PCR were } 1 \text { cycle of } 95^{\circ} \mathrm{C} \text { for for } 15 \mathrm{~min} ; 50 \text { cycles of } 95 \text { for } \\
15 \mathrm{sec}, 65^{\circ} \mathrm{C} \text { for } 30 \mathrm{sec} \text {, and } 72^{\circ} \mathrm{C} \text { for } 30 \mathrm{sec} \text {. }\end{array}$ & Pei et al. 2006 \\
\hline & sul (II) & $\begin{array}{l}9 \mu \mathrm{l} \text { of } 5 \text { PrimeMasterMix (5Prime, Gaithersburg MD), } 0.4 \mu \mathrm{l} \\
\text { of each primer (100mM), } 1 \mu \mathrm{l} \text { of template DNA, and reagent- } \\
\text { grade water in a final reaction volume of } 20 \mu \mathrm{l} \text {. }\end{array}$ & $\begin{array}{l}\text { PCR were } 1 \mathrm{cycle} \text { of } 95^{\circ} \mathrm{C} \text { for for } 15 \mathrm{~min} ; 50 \text { cycles of } 95 \text { for } \\
15 \mathrm{sec}, 57.5^{\circ} \mathrm{C} \text { for } 30 \mathrm{sec} \text {, and } 72^{\circ} \mathrm{C} \text { for } 30 \mathrm{sec} \text {. }\end{array}$ & Pei et al. 2006 \\
\hline$\beta$-lactamases & CTX-M, CMY-2 & $\begin{array}{l}\text { 10ul of Jumpstart Red Taq Master Mix (Sigma, St. Louis MO) } \\
\text { was combined with } 0.2 \mathrm{ul} \mathrm{CMY2} \mathrm{primers}(200 \mathrm{mM}) \text { and } 0.3 \mathrm{ul} \\
\text { CTX-M primers ( } 200 \mathrm{mM}), 1 \mathrm{ul} \text { of extracted DNA and reagent- } \\
\text { grade water for a total reaction volume of } 20 \mathrm{ul} \text {. }\end{array}$ & $\begin{array}{l}\text { One cycle consisting of } 15 \mathrm{~min} \text { at } 94^{\circ} \mathrm{C}, 30 \text { cycles consisting } \\
\text { of } 1 \mathrm{~min} \text { at } 94^{\circ} \mathrm{C}, 1 \mathrm{~min} \text { at } 55^{\circ} \mathrm{C} \text {, and } 1 \mathrm{~min} \text { at } 72^{\circ} \mathrm{C} \text {, and one } \\
\text { cycle consisting of } 10 \mathrm{~min} \text { at } 72^{\circ} \mathrm{C} \text {. }\end{array}$ & $\begin{array}{l}\text { Cottell et al., } \\
\text { 2013; Kozak et } \\
\text { al., } 2009\end{array}$ \\
\hline
\end{tabular}

Quantitative PCR

\begin{tabular}{|c|c|c|c|c|}
\hline Resistance & Genes & PCR Recipie Used & Themocycling Conditions Used & Reference \\
\hline Tetracycline & tet $(\mathrm{A})$ & QuantiTect SYBR Master Mix (Qiagen, Valencia CA) & $\begin{array}{l}1 \mathrm{cycle} \text { of } 94^{\circ} \mathrm{C} \text { for } 15 \mathrm{~min} ; 35 \text { cycles of } 94^{\circ} \mathrm{C} \text { for } 1 \mathrm{~min}, 55 \text { for } \\
1 \mathrm{~min}, 72^{\circ} \mathrm{C} \text { for } 90 \mathrm{sec} ; 1 \mathrm{cycle} \text { of } 72^{\circ} \mathrm{C} \text { for } 5 \mathrm{~min}\end{array}$ & Ng et al. 2001 \\
\hline Sulfonamide & sul (I) & 5Prime RealMasterMix SYBR ROX (5Prime, Gaithersburg MD) & $\begin{array}{l}95^{\circ} \mathrm{C} \text { for } 15 \mathrm{~min} ; 50 \text { cycles of } 95^{\circ} \mathrm{C} \text { for } 15 \mathrm{sec}, 65^{\circ} \mathrm{C} \text { for } 30 \\
\mathrm{sec}, 72^{\circ} \mathrm{C} \text { for } 30 \mathrm{sec}\end{array}$ & Pei et al., 2006 \\
\hline
\end{tabular}

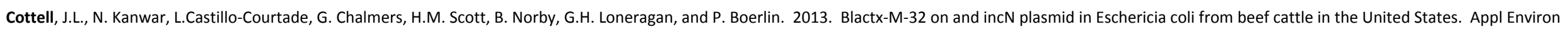
Microbiol. 57:10-96-1097.

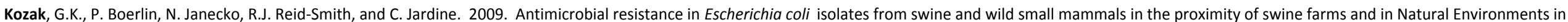
Ontario, Canada. Appl Environ Microbiol. 75:559-566.

Ng, L.K., I. Martin, M. Alfa, and M. Mulvey. 2001. Multiplex PCR for the detection of tetracycline resistant genes. Mol. Cell. Probes. 15:209-215.

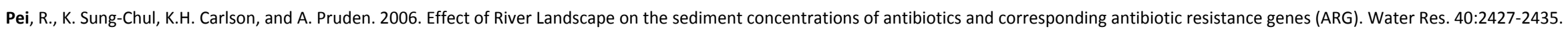




\section{Assessment of Selected Antibiotic Resistances in Ungrazed Native Nebraska Prairie Soils}

\section{Table S3: Soil Physical and Chemical Data}

Contact person: Lisa Durso lisa.durso@ars.usda.gov

\begin{tabular}{|c|c|c|c|c|c|c|c|c|c|c|c|c|c|c|c|}
\hline $\begin{array}{l}\text { Prairie } \\
\text { ID } \\
\end{array}$ & $\begin{array}{c}\text { Moisture } \\
\text { Content }\end{array}$ & $\mathrm{pH}$ & $\begin{array}{c}\text { Organic } \\
\text { Matter } \\
\text { (LOI \%) } \\
\end{array}$ & $\begin{array}{c}\text { Potassium } \\
\text { K (ppm) }\end{array}$ & $\begin{array}{c}\text { Sulfate-S } \\
\text { S (ppm) }\end{array}$ & $\begin{array}{c}\text { Zinc } \\
\text { Zn } \\
\text { (ppm) } \\
\end{array}$ & $\begin{array}{c}\text { Iron } \\
\text { Fe } \\
\text { (ppm) }\end{array}$ & $\begin{array}{c}\text { Manganese } \\
\text { Mn (ppm) }\end{array}$ & $\begin{array}{c}\text { Copper } \\
\text { Cu } \\
\text { (ppm) }\end{array}$ & $\begin{array}{l}\text { Calcium } \\
\text { Ca (ppm) }\end{array}$ & $\begin{array}{c}\text { Magnesium } \\
\text { Mg (ppm) }\end{array}$ & $\begin{array}{c}\text { Sodium } \\
\mathrm{Na} \\
\text { (ppm) }\end{array}$ & $\begin{array}{c}\text { KCl NO3- } \\
\text { N NO3 } \\
\text { (ppm) }\end{array}$ & $\begin{array}{l}\text { KCl NH4- I } \\
\text { N (ppm) }\end{array}$ & $\begin{array}{c}\text { Mehlich P-III } \\
\text { (ppm) }\end{array}$ \\
\hline 1 & 9.74 & 6.98 & 4.38 & 253 & 8.4 & 1.4 & 62.8 & 11.4 & 1.018 & 2198.2 & 370.8 & 11.2 & 1.34 & 11.88 & 5.6 \\
\hline 2 & 12.63 & 6.92 & 3.94 & 210.6 & 8.2 & 0.932 & 64.88 & 8.68 & 1.15 & 1917.6 & 474 & 24.6 & 1 & 11.22 & 3 \\
\hline 3 & 24.33 & 6.76 & 5.82 & 211.2 & 14.4 & 1.424 & 77.48 & 22.86 & 1.546 & 3072.8 & 347 & 33 & 1.86 & 12.98 & 4.2 \\
\hline 4 & 20.33 & 6.76 & 3.52 & 254 & 17.6 & 0.93 & 91.9 & 20.46 & 2.046 & 3575.6 & 640.6 & 19 & 2.88 & 14 & 13.2 \\
\hline 5 & 21.84 & 6.74 & 5.28 & 165.2 & 11 & 1.144 & 83.32 & 14.28 & 1.494 & 1993.6 & 347.4 & 13.2 & 1.02 & 12.38 & 2.4 \\
\hline 6 & 20.94 & 6.88 & 6.2 & 210 & 8 & 1.1 & 65.12 & 23.36 & 1.202 & 3687.4 & 394.6 & 54 & 2.04 & 10.94 & 2.4 \\
\hline 7 & 17.87 & 6.92 & 6.76 & 247.8 & 8.4 & 2.268 & 57.02 & 15.28 & 1 & 2758.2 & 290.2 & 17.2 & 2.9 & 9.96 & 3.8 \\
\hline 8 & 10.62 & 6.87 & 5.1 & 94.8 & 8.4 & 1.524 & 108.7 & 11.78 & 1.412 & 2210.2 & 407 & 31.2 & 2.44 & 12.24 & 2.4 \\
\hline 9 & 12.94 & 6.97 & 5.14 & 220.2 & 7.4 & 1.212 & 60.7 & 12.76 & 1.046 & 2125.6 & 303.2 & 5 & 1.32 & 9.36 & 4.2 \\
\hline 10 & 14.44 & 6.78 & 5.6 & 162.4 & 10 & 1.22 & 44.74 & 15.82 & 1.222 & 3597 & 228.6 & 13.2 & 4.46 & 12.46 & 3.4 \\
\hline 11 & 16.32 & 6.81 & 4.72 & 114 & 7.2 & 1.292 & 81.58 & 10.56 & 1.28 & 2094.6 & 278.8 & 15.6 & 1.14 & 11.5 & 2.4 \\
\hline 12 & 12.63 & 6.88 & 4.82 & 246.8 & 9.2 & 1.394 & 73.5 & 8.3 & 0.984 & 1763.6 & 339.2 & 9.6 & 1.36 & 13.42 & 4.6 \\
\hline 13 & 20.10 & 6.92 & 4.84 & 128 & 7.2 & 1.23 & 77.2 & 16.5 & 1.354 & 2914 & 246.4 & 18.6 & 1.06 & 11.68 & 2.8 \\
\hline 14 & 23.38 & 6.70 & 6.06 & 207.4 & 13.4 & 0.912 & 40.06 & 30.1 & 1.412 & 3715.2 & 271 & 21 & 1.28 & 14.74 & 2.8 \\
\hline 15 & 10.10 & 6.98 & 5.28 & 313.8 & 10.6 & 1.042 & 39.02 & 11.3 & 1.108 & 2949.8 & 397 & 8 & 1.26 & 13.76 & 4.6 \\
\hline 16 & 11.53 & 6.88 & 4.64 & 186.8 & 8.2 & 1.512 & 164.9 & 9.52 & 1.226 & 1850.6 & 384.6 & 32.6 & 1.1 & 10.18 & 3.5 \\
\hline 17 & 11.51 & 6.90 & 5.22 & 161.6 & 10.6 & 1.542 & 97.18 & 13.98 & 1.27 & 2301.2 & 417.4 & 18.4 & 1.72 & 12.16 & 3.8 \\
\hline 18 & 15.12 & 6.87 & 5.08 & 283 & 7.8 & 0.976 & 67.5 & 13.36 & 1.228 & 2491.2 & 508.4 & 9 & 1.46 & 16.98 & 4.4 \\
\hline 19 & 24.34 & 7.04 & 5.56 & 219.4 & 11.4 & 0.564 & 29.44 & 23.26 & 0.87 & 5317.8 & 101.4 & 5.8 & 2.14 & 14.66 & 3.4 \\
\hline 20 & 11.07 & 6.89 & 4.38 & 141.8 & 9.2 & 1.544 & 84.2 & 12.26 & 1.16 & 1778.8 & 371.4 & 42 & 2.18 & 12.26 & 3.4 \\
\hline
\end{tabular}

$\mathrm{ND}=$ Not detected 